\title{
Open tray impression technique using a silica-nylon mesh for splitting implants: a case report
}

Técnica de moldagem de moldeira aberta com malha de sílica-nylon para esplintagem de implantes: relato de caso clínico

La técnica de impresiones en cubeta abierta con malla de sílice-nylon para ferulización de implantes: reporte de caso clínico

Tarcisio José de Arruda PAES-JUNIOR ${ }^{1}$ Paolo FREITAS ${ }^{2}$ Renato Sussumu NISHIOKA ${ }^{3}$

Gabriela Nogueira de Melo NISHIOKA Leonardo Jiro Nomura NAKANO ${ }^{5}$

${ }^{1} D D S$ MD PhD Associate Professor of São Paulo State University (Unesp), Institute of Science and Technology, São José dos Campos - SP, Brazil ${ }^{2}$ DDS Clinical Dentistry Expert at São Paulo State University (Unesp), Institute of Science and Technology, São José dos Campos - SP, Brazil ${ }^{3}$ DDS MD PhD Full Professor of Prosthodontics of São Paulo State University (Unesp), Institute of Science and Technology, São José dos Campos - SP, Brazil ${ }^{4}$ DDS MSc Master Science of São Paulo State University (Unesp), Institute of Science and Technology, São José dos Campos - SP, Brazil

${ }^{5}$ DDS MD Post Graduate Student of São Paulo State University (Unesp), Institute of Science and Technology, São José dos Campos - SP, Brazil

\section{Abstract}

This article describes an alternative open tray technique for implant impressions using a novel reinforced silica-nylon mesh covered with acrylic resin as a splitting system in assembling the abutment complex. The purpose of the procedure is to simplify the technique and improve the resin contraction during clinical procedure, and also optimizes and reduces the chairside time for the patient. The clinical report was supported by an in vitro study where an analysis tool, Strain Gauge Analysis, was used to prove the clinical effectiveness of the technique. The peri-implant strain was determined on polyurethane casts with the torqued prosthesis, and statistically there was no difference in strain under torque of transfers or in the final prosthesis. The nylon mesh attached to acrylic resin represents a promising option for open tray impression technique, creating a resistant union to transfer in an excellent procedure time.

Descriptors: Dental Implants; Dental Prosthesis; Nylons; Computer Simulation.

\section{Resumo}

Este artigo descreve uma alternativa para a técnica de moldeira aberta para moldagem de implantes utilizando uma nova malha de reforço de sílica-nylon coberta por resina acrílica para ferulização dos componentes protéticos. O propósito deste procedimento é simplificar a técnica e compensar a contração da resina durante os procedimentos clínicos, e também otimizar e reduzir o tempo de atendimento do paciente. O relato de caso foi amparado com um estudo in vitro onde uma ferramenta de análise de extensometria, Análise de Strain Gauge, foi utilizada para avaliar a efetividade clínica da técnica. A deformação periimplantar foi determinada nas bases de poliuretano com a prótese instalada, e estatisticamente não houve diferença estatística na deformação nos torques dos transferentes ou na prótese final. A malha de nylon unida à resina acrílica representa uma opção promissora para a técnica de moldagem com moldeira aberta, criando uma união resistente aos transferentes em um excelente tempo clínico.

Descritores: Implantes Dentários; Prótese Dentária; Nylons; Simulação por Computador.

\section{Resumen}

Este estudio describe una técnica alternativa de cubeta abierta para impresiones de implantes utilizando una nueva malla de sílice-nylon cubierta con resina acrílica como un sistema de ferulización en montaje del complejo de pilares. El objetivo del procedimiento es simplificar la técnica y mejorar la contracción de la resina durante el procedimiento clínico y también optimiza y reduce el tiempo de atención al paciente. El relato clínico fue respaldado por un estudio in vitro en el que se utilizó una herramienta de análisis, Análisis de Galgas Extensométricas, para probar la efectividad clínica de la técnica. La deformación periimplantaria se determinó en moldes de poliuretano con la prótesis apretada, y estadísticamente no hubo diferencia en la deformación del torque de los postes o en la prótesis final. La malla de nylon unida a la resina acrílica representa una opción prometedora para la técnica de impresión en cubeta abierta, creando una unión resistente para transferir en un excelente tiempo de procedimiento.

Descriptores: Implantes Dentales; Prótesis Dental; Nylons; Simulación por Computador.

The loss of dental elements compromises the body's physiological system ${ }^{1}$ and causes internal oral collapse ${ }^{2,3}$ as well as affecting patient's physical and social wellbeing ${ }^{4,5}$. Therefore, the restitution of lost dental elements is very important and the challenge for restorative dental surgeons is to return aesthetics and function to the patient ${ }^{6}$.

Oral implant rehabilitation with fixed dental prostheses requires several steps to final restoration and to achieve a precision of fit. In implant-supported prostheses the accurate reproduction of the implant position is essential ${ }^{7}$. Marginal fit is a key factor and inaccuracies in the prosthesis can lead to failure ${ }^{8-10}$. Normal practice requires attention to the impression technique, impression material, stone properties, and connection type to make a flawless prosthesis ${ }^{11}$. The choice of impression materials and techniques (closed tray or indirect technique, and open tray or direct technique) are fundamental to obtaining correct register in the three-dimensional position of the implants ${ }^{7,12,13}$. The direct technique may use splinted or non splinted implant impression coping ${ }^{14}$. The process of luting the cylinders with self-curing acrylic resin directly in the patient's mouth is a careful exercise; the technique required application of the acrylic resin filling with a small paintbrush in increments, cutting the assembly with a thin disc after stabilization of the acrylic resin and luting the assembly together again. Shrinkage of the acrylic resin may hamper the accuracy of the cast ${ }^{15,16}$. 
Recently, an experimental silica-nylon mesh was developed to reinforce acrylic resin prostheses; the promising results showed an increase in the strength of the restoration ${ }^{17,18}$. This new material is also available for interim acrylic resin in an open tray technique instead of dental floss connected to the transfers to create a structure to support the acrylic resin during an implant impression. This may be less timeconsuming than intraoral.

This material was manufactured to optimize the precision results of molding and reduce the time taken to complete the clinical procedure. Nylon mesh is modified by the addition of silica at the proportion of $0.5 \%$ of the total volume ${ }^{19}$. This case report describes the use of a new mesh tested with acrylic resin to connect implants or abutments and suggests a clinical guideline for implant impression technique.

In this case report, a Strain Gauge Analysis (SGA) was included just to illustrate a possible stress condition on the tissues when using this alternative open tray technique for implant impressions that allowed the metallic structure of the implants to be obtained in a single body without requiring framework section and soldering.

CLINICAL CASE

A 53-year-old woman sought prosthodontics treatment for dental implants. The patient presented with dental loss of lower central incisors, which occurred several years before, and she expressed the wish to smile again. A complete medical history was obtained in the first appointment, along with an impression of the superior and inferior dental arch. In the next visit, the clinical practitioner extracted lower lateral incisors under local anesthetic, mepivacaine 3\% (Mepivacaine DFL, Mepiadre 100, Brazil), and immediately postextraction, performed 2 implants. The sequence of drills to prepare the site was: pilot; $2.0 ; 2.5$; 2.8; 3.0, and $3.2 \mathrm{~mm}, 3.75 \times 13 \mathrm{~mm}$ (Cone Morse EX, Neodent, São Paulo, Brazil). Two transmucosal abutments, 2.5mm (Micro pilar Cone Morse, Neodent, São Paulo, Brazil), were screwed on implants and a provisional acrylic resin crown was placed under immediate loading. Patients have shown successful outcomes when treated with immediate implant placement, post-extraction, in comparison to traditional technique where the placement is delayed; this also enhances healing procedures, preserving the morphology of hard and soft tissues.

After a 4-month healing phase, the prosthetic treatment was continued.
The following technique describes an alternative open tray impression for multiple implants used a nylon mesh connected to acrylic resin (Duralay; Reliance Dental). This procedure ensures stability. Two transfers were placed intraoral and firmly screwed on abutments. The impression trays were customized with holes according to the position of the transfers (Figure 1). For a conventional impression, floss is essential to create a structure for the acrylic resin; in this case, the nylon mesh takes the place of the dental floss, in a simple and fast step (Figure 2).

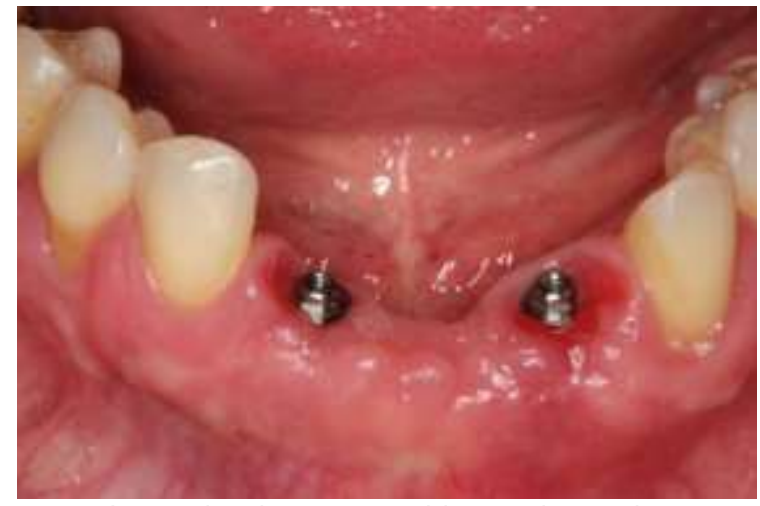

Figure 1: Intraoral - abutments and impression copings screwed onto abutments.

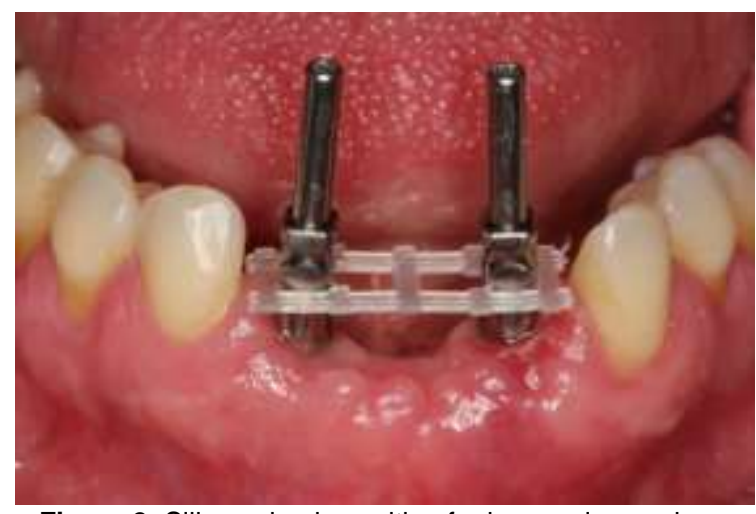

Figure 2: Silica-nylon in position for impression copings.

The acrylic resin was molded with power, (polymer) and liquid (monomer) was applied with a paintbrush supported by the nylon mesh. After polymerization of the acrylic resin, the clinician started the impression. The resin was not sectioned and reconnected for open tray impression copings (Figure 3).

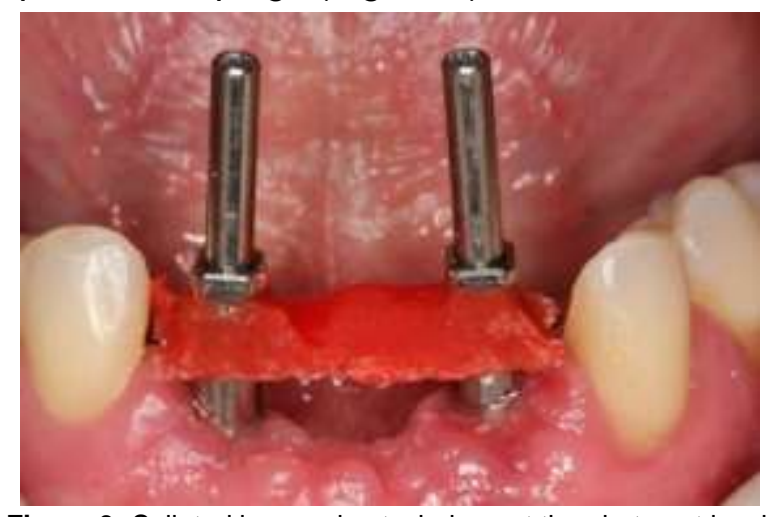

Figure 3: Splinted impression technique at the abutment level. 
All tissues were cleaned and dried. The impression was injected with a medium-bodied silicone material (Zhermack; Elite HD) in an impression tray, and light-bodied silicone (Zhermack; Elite HD) was placed in the patient's mouth and onto the medium-bodied silicone (Figure 4).

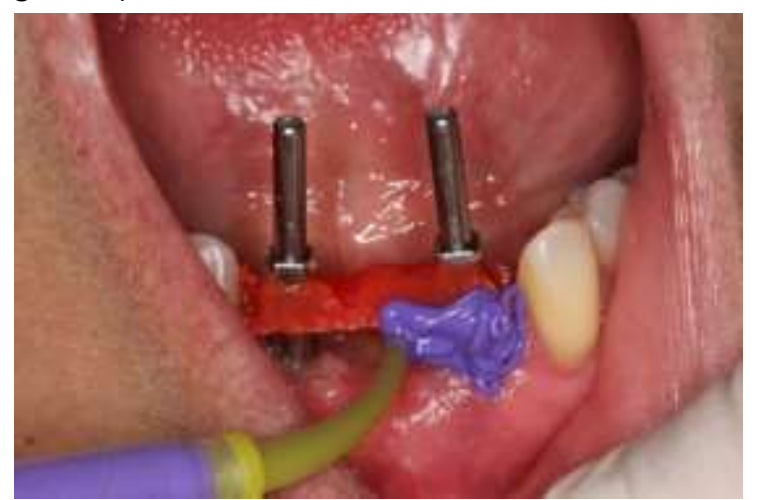

Figure 4: Injection of soft material by syringe around each implant and tissue.

Once the impression material was polymerized, the transfers were unscrewed and removed from the patient's mouth (Figure 5). The cover was replaced, and the pickup analogs of the abutment were gently screwed in the transfers. For this study, one open tray was cast in the prosthetic laboratory and another impression was set in the same clinical conditions as the simulation in the in vitro test. The stress around the implant-abutment was recorded with strain gauge analysis.

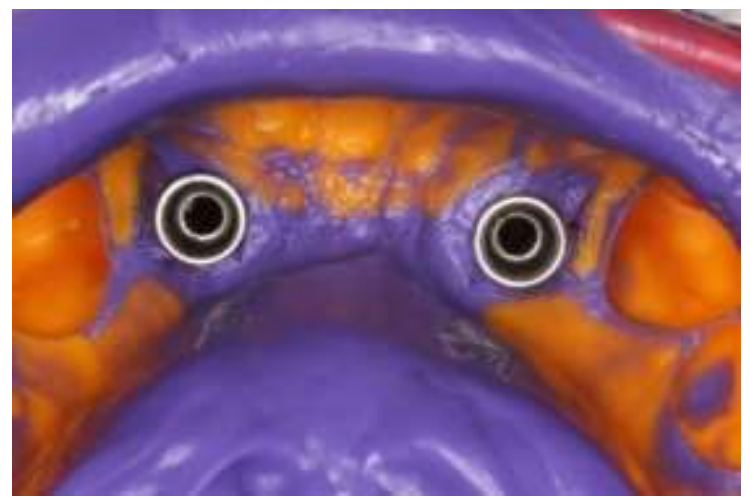

Figure 5: Tray filled with elastomeric material and the impression recorded. Once the impression set, the guide pin (impression coping) was unscrewed and removed from the patient's mouth, the impression tray with the transfer coping bound with acrylic resin and retained within the impression material.

A silicone gingival mask (Gingifast; Zhermack) was set around the abutments to reproduce gum morphology in the cast, with the same dimensions as the implant inserted in the patient. The dental stone type IV (Zero stone; Dentona) was poured into the impression tray and once the material was set, it was removed from the silicone impression. The fixed dental prosthesis was made by conventional technique with a metal substructure of $\mathrm{Ni}-\mathrm{Cr}$ alloy and a feldspathic ceramic covering (Figures 6 and 7).

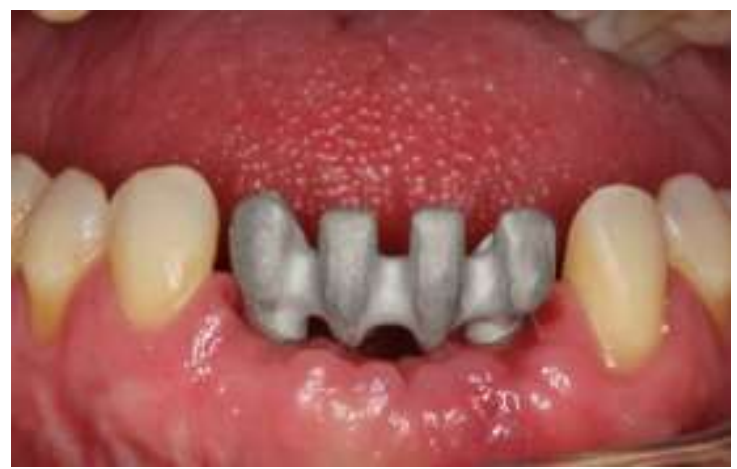

Figure 6: Metal substructure of $\mathrm{Ni}-\mathrm{Cr}$ alloy of the fixed dental prosthesis.

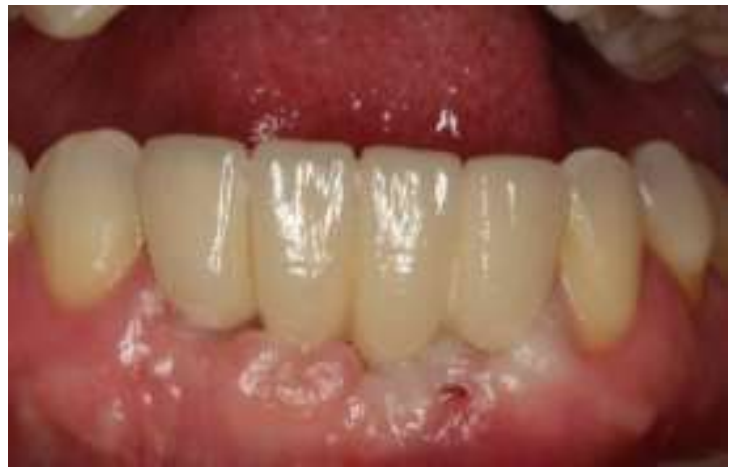

Figure 7: Buccal view of final prosthesis.

Polyurethane was used in an open tray for the in vitro study. For SGA, the gauges (KFG-02-120-C1-11N30C2; Kyowa Electronic Instruments; Co. Ltd.) were positioned and attached with methyl-2-cyanoacrylate adhesive (Super Bonder, Loctite) on the upper surface of the experimental model next to the implants and held in place under slight pressure for 3 minutes (Figures 8 and 9).

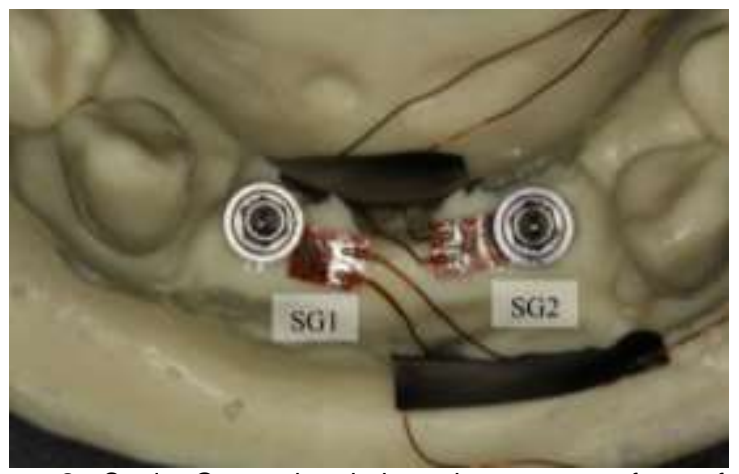

Figure 8: Strain Gauge bonded to the upper surface of the polyurethane cast.

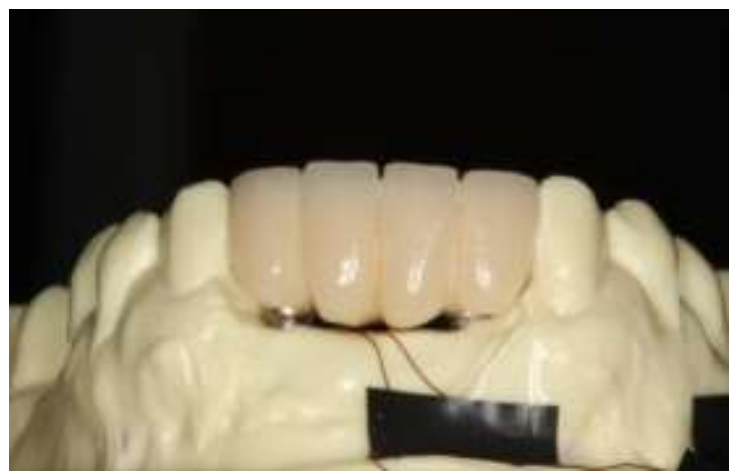

Figure 9: Final prosthesis in position and screwed into the polyurethane cast. 
Each SG (SG1 and SG2) was related to the wire separately and connected to a multichannel bridge amplifier, to form one leg of the bridge. An analysis program (System 5000, Model 5100 Scanner, Vishay Measurements Group, Raleigh, NC) was used to measure, record, and process the strain values induced around the implant when torque was achieved during performance of the transfers and in the final prosthesis (Table I).

Table I. Mean values from 2 strain gauges in polyurethane cast. Impression coping and the final prosthesis were tested.

\begin{tabular}{l|c|c|c|c|c|c|c|c}
\hline Variable & SG & $\mathbf{N}$ & Mean & StDev & CoefVar & Minimum & Median & Maximun \\
\hline Impression & 1 & 5 & 1254.8 & 60.4 & 4.81 & 1191.0 & 1249.0 & 1339.0 \\
\cline { 2 - 9 } Coping & 2 & 5 & 994.2 & 46.3 & 4.65 & 966.0 & 985.0 & 1071.0 \\
\hline \multirow{2}{*}{ Prothesis } & 1 & 5 & 1295.2 & 57.2 & 4.41 & 1256.0 & 1267.0 & 1394.0 \\
\cline { 2 - 9 } & 2 & 5 & 910.0 & 199.7 & 21.94 & 646.0 & 1025.0 & 1072.0 \\
\hline
\end{tabular}

RESULTS

The metallic infrastructure was prepared and tested in place. During this clinical evaluation, it was noted that there was no requirement to section the infrastructure. The metal-ceramic crown showed passive fit, no adjustment was made.

The mean values of this in vitro study showed the following results: strain values were 1254 (SG1) and 994 (SG2) when the impression copings were screwed in, and in the final prosthesis were 1295 (SG1) and 910 (SG2). There was little difference between each strain gauge. No significant difference was detected between the impression copings and the prosthesis.

DISCUSSION

The open tray technique has several advantages in term of greater precision, stability, and accuracy compared with the closed technique ${ }^{19,20}$. The material of choice for implant impression is polyvinyl siloxane (additionsilicone) or polyether. Both classes of material can be used by the clinician ${ }^{13,19,21}$.

In an attempt to provide a master cast that replicated the clinical situation, the implants must be splinted to obtain accuracy ${ }^{22}$. The splinted technique can be with acrylic resin, visible light-cured resin or Protemp (bis-GMA resin) ${ }^{22-26}$. In implantodontology, the clinical procedures for taking an impression imply a precision technique to obtain exact dimensions of the mouth and even the most experience practitioner can encounter difficulties ${ }^{22}$. In order to stabilize the tray and the molding material, the use of open tray direct pick-up impression technique is the standard solution when performing multiple implants ${ }^{27}$. An ideal technique should be easy to perform, involve minimal time, be comfortable for the patient, and should produce accurate results ${ }^{14}$.

In particular, when using this new nylon mesh to support acrylic resin, which is easy to handle and more effective in reducing the time spent creating an accurate master cast, the strain gauge analysis did not reveal differences when screwing in the implant impression copings or the final prosthesis. This indicates no stress for the bone tissue.

Another aspect that must be considered when using nylon mesh to support a resin, is that the mesh creates a structure more resistant then dental floss with resin. The clinical report reveals accurate (precision as result of splitting stability) working cast and reduction of chair time, which results in patient satisfaction.

In addition, the in vitro study showed similar results between the implant impression coping and the final prosthesis, considering the material used in this study. The mean strain values for final prosthesis were 1295 (SG1) and 910 (SG2). Other authors have observed similar results in the range of strain in implantsupported prostheses ${ }^{28-30}$.

Because there are improvements in all impression materials, the open tray technique using experimental novel nylon silica may serve as a viable option for any clinician. Further studies evaluating the impression techniques using nylon mesh are necessary.

CONCLUSION

This clinical report described an alternative technique. The nylon mesh attached to acrylic resin represents a promising option for open tray impression technique, creating a resistant union to transfer in an excellent procedure time.

\section{REFERENCES}

1. Freitas RF, Dias KC, Carreiro AFP, Barbosa GA, Ferreira MA. Mandibular Implant-supported removable partial denture with distal extension: a systematic review. J Oral Rehabil. 2012; 39:791-98.

2. Craddock HL. Consequences of tooth loss (part 1): The patient perspective-aesthetic and functional implications. Sadj. 2010;65:242-45.

3. Craddock HL. Consequences of tooth loss (part 2): dentist considerations-restorative problems and implications. Sadj. 2010;65:292-96.

4. Flanagan D. Avoiding osseous grafting in the atrophic posterior mandible for implantsupported fixed partial dentures: a report of 2 cases. J Oral Implantol. 2011;37:705-11.

5. Kisely S, Baghaie $H$, Lallo $R$, Siskind D, Johnson NW. A systematic review and metaanalysis of the association between poor oral health and severe mental illness. Psychosom Med. 2015;77:83-92.

6. Jin LJ, Lamster I, Greenspan JS, Pitts N, Scully C, Warnakulasuriya S. Global Burden of oral 
diseases: emerging concepts, management and interplay with systemic health. Oral Dis. 2016;22(7):609-19.

7. Kumar $Y$, Chand $P$, Arova V, Singh Sv, Mishra $\mathrm{N}$, Alvi HA, Verma UP. Comparison of rehabilitating missing mandibular first molars with implant or tooth-supported prostheses using masticatory efficiency and patient satisfaction outcomes. J Prosthodont. 2017; 26:376-80.

8. Cerqueira NM, Ozcan M, Gonçalves M, da Rocha DM, Vasconcellos DK, Bottino MA, Yener-Salihoğlu E. A strain gauge analysis of microstrain induced by various splinting methods and acrylic resin types for implant impressions. Int J Oral Maxillofac Implants. 2012;27:341-45.

9. Revilla-León M, Sánchez-Rubio JL, OteoCalatayud J, Özcan M. Impression technique for a complete-arch prosthesis with multiple implants using additive manufacturing technologies. J Prosthet Dent. 2017;117: 714-20.

10. Alqahtani F. Marginal fit of all-ceramic crowns fabricated using two extraoral CAD/CAM systems in comparison with the conventional technique. Clin Cosmet Investig Dent. 2017; 16:13-8.

11. Papaspyridakos $P$, Hirayama $H$, Chen $C J$, Ho $\mathrm{CH}$, Chronopoulos V, Weber HP. Full-arch implant fixed prostheses: a comparative study on the effect of connection type and impression technique on accuracy of fit. Clin Oral Implants Res. 2016;27:1099-105.

12. Balshi TJ, Wolfinger GJ, Alfano SG, Cacovean JN, Balshi SF. Fabricating an Accurate Implant Master Cast: A Technique Report. J Prosthodont. 2015;24:654-60.

13. Gayathridevi SK, Gowda H, Vaishali K, Suma. Impression Techniques in Implants. J Dent Orofac Res. 2016;12:11-9.

14. Del'Acqua MA, Chávez AM, Compagnoni MA, Molo Fde A Jr. Accuracy of impression techniques for an implant-supported prosthesis. Int J Oral Maxillofac Implants. 2010;25:715-21.

15. Norman C, Michael Klein, Simons A. Atlas of Oral Implantology. Second Edition. St Louis, Mo: Mosby Year Book; 1999.

16. Lee SJ, Cho SB. Accuracy of five implant impression technique: effect of splinting materials and methods. J Adv Prosthodont. 2011;3:177-85.

17. Almeida CS, Amaral M, Gonçalves FCP, PaesJunior TJA. Effect of an experimental silicanylon reinforcement on the fracture load and flexural strength of bisacrylic interim partial fixed dental prostheses. J Prosthet Dent. 2016;115:301-5.

18. Gonçalves FCP, Amaral M, Borges ALS, Gonçalves LFM, Paes-Junior TJA. Fracture load of complete-arch implant-supported prostheses reinforced with nylon-silica mesh: An in vitro study. J Prosthet Dent. 2017; 119:606-10.

19. Wegner K, Weskott K, Zenginel M, Rehmann P, Wöstmann B. Effects of implant system, impression technique, and impression material on accuracy of the working cast. Int $\mathrm{J}$ Oral Maxillofac Implants. 2013;28:989-95.

20. Alikhasi M, Siadat H, Beyabanaki E, Kharazifard MJ. Accuracy of implant position transfer and surface detail reproduction with different impression materials and techniques. $J$ Dent (Tehran). 2015;12:774-83.

21. Lorenzoni M, Pertl C, Penkner K, Polansky R, Sedaj B, Wegscheider WA. Comparison of the transfer precision of three different impression materials in combination with transfer caps for the Frialit-2 system. Oral Rehabil. 2000;27: 629-38.

22. Selvaraj S, Dorairaj J, Mohan J, Simon P. Comparison of implant cast accuracy of multiple implant impression technique with different splinting materials: An in vitro study. J Indian Prosthodont Soc. 2016;16:167-75.

23. Moreira AH, Rodrigues NF, Pinho AC, Fonseca JC, Vilaça JL. Accuracy comparison of implant impression techniques: a systematic review. Clin Implant Dent Relat Res. 2015;17:751-64.

24.Zen BM, Soares EF, Rodrigues MA, Luthi LF, Consani RL, Mesquita MF, Henriques GE. Comparison of the accuracy of different transfer impression techniques for osseointegrated implants. J Oral Implantol. 2015;41:662-7.

25. Gennari Filho H, Mazaro JV, Vedovatto E, Assunção WG, dos Santos PH. Accuracy of impression techniques for implants. Part 2 comparison of splinting techniques. J Prosthodont. 2009;18:172-6.

26. Ongül D, Gökçen-Röhlig B, Şermet B, Keskin $\mathrm{H}$. A comparative analysis of the accuracy of different direct impression techniques for multiple implants. Aust Dent J. 2012;57:184-9.

27. Siadat H, Alikhasi M, Beyabanaki E, Rahimian S. Comparison of different impression techniques when using the all-on-four implant treatment protocol. Int $\mathrm{J}$ Prosthodont. 2016;29:265-70.

28. Chen $X Y$, Zhang $C Y$, Nie EM, Zhang MC. Treatment planning of implants when 3 mandibular posterior teeth are missing: a 3dimensional finite element analysis. Implant Dent. 2012;21:340-3.

29. Karl M, Holst S. Strain development of screwretained implant-supported fixed restorations: procera implant bridge versus conventionally cast restorations. Int J Prosthodont. 2012; 25:166-9.

30. Waskewicz GA, Ostrowski JS, Parks VJ. Photoelastic analysis of stress distribution transmitted from a fixed prosthesis attached to osseointegrated implants. Braz Oral Res. 2004;18:45-52. 


\section{CONFLICTS OF INTERESTS}

The authors declare no conflicts of interests.

\section{CORRESPONDING AUTHOR}

\section{Leonardo Jiro Nomura Nakano}

DDS; MD

Post Graduate Student - Ph.D Program, Department of Dental Materials and Prosthodontics, São Paulo State University (Unesp), Institute of Science and Technology, São José dos Campos - SP.

Avenida Engenheiro Francisco José Longo, 777, Jardim São Dimas, São José dos Campos - SP, CEP: 12245000.

Phone: +55 (15) 98139-0402

ORCID: https://orcid.org/0000-0001-6786-862X

E-mail: jiro_nakano@hotmail.com 